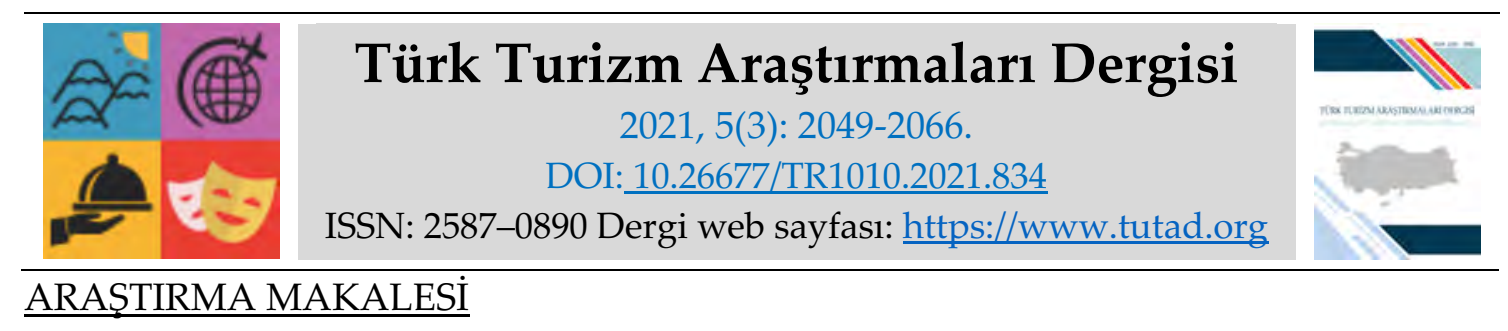

\title{
Presenteizmin Örgütsel Bağlılık Üzerindeki Etkisi: Adana İlinde Faaliyet Gösteren Yiyecek-İçecek İşletmeleri Üzerine Bir Araştırma
}

Dr. Öğr. Üyesi Fatih ÖZDEMIR, İskenderun Teknik Üniversitesi, Turizm Fakültesi, Hatay, eposta: fatih.ozdemir@iste.edu.tr

ORCID: https://orcid.org/0000-0002-9087-6211

İsmail DEMİRCİ, Yüksek Lisans Öğrencisi, İskenderun Teknik Üniversitesi, Lisansüstü Eğitim Enstitüsü, Adana, e-posta: idemirci.lee@iste.edu.tr

ORCID: https://orcid.org/0000-0002-2416-1912

Öz

Presenteizm, bir kişinin kendini fiziken ya da ruhen iyi hissetmemesine rağmen yaptığ devam etmesi sonucu ortaya çıkan bir olumsuzluktur. Örgütsel Bağlllık ise örgüt ile çalışanlarının değer ve çıkarlarının birleşmesi olarak ifade edilebilir. Bu doğrultuda çalışmada Adana İlinde faaliyet gösteren Yiyecek-İçecek İşletmelerinde istihdam edilen iş görenin maruz kaldığı Presenteizm durumunun Örgütsel Bağlllık düzeyleri üzerinde herhangi bir etkisinin olup olmadığının ortaya konması amaçlanmıştır. Alan araştırmasında nicel desen tercih edilmiş ve veriler anket tekniğiyle toplanmıştır. Veri analizinde frekans, güvenilirlik, faktör, korelasyon ve regresyon analiz teknikleri kullanılmıştır. Yapılan analizler sonucu presenteizmin örgütsel bağlılık ile herhangi bir anlamlılık ilişkisi tespit edilemezken, örgütsel bağlllığın alt boyutu olan normatif bağlılı̆̆ın üzerinde negatif ve anlamlı yönde bir etkisi tespit edilmiştir.

Anahtar Kelimeler: Presenteizm, Örgütsel Bağlllık, Yiyecek-İçecek İşletmeleri, Adana.

Makale Gönderme Tarihi: 06.05.2021

Makale Kabul Tarihi: 04.09.2021

\section{Önerilen Atıf:}

Özdemir, F. ve Demirci, İ. (2021). Presenteizmin Örgütsel Bağlllık Üzerindeki Etkisi: Adana İlinde Faaliyet Gösteren Yiyecek-İçecek İşletmeleri Üzerine Bir Araştırma, Türk Turizm Araştırmaları Dergisi, 5(3): 2049-2066.

(c) 2021 Türk Turizm Araştırmaları Dergisi. 


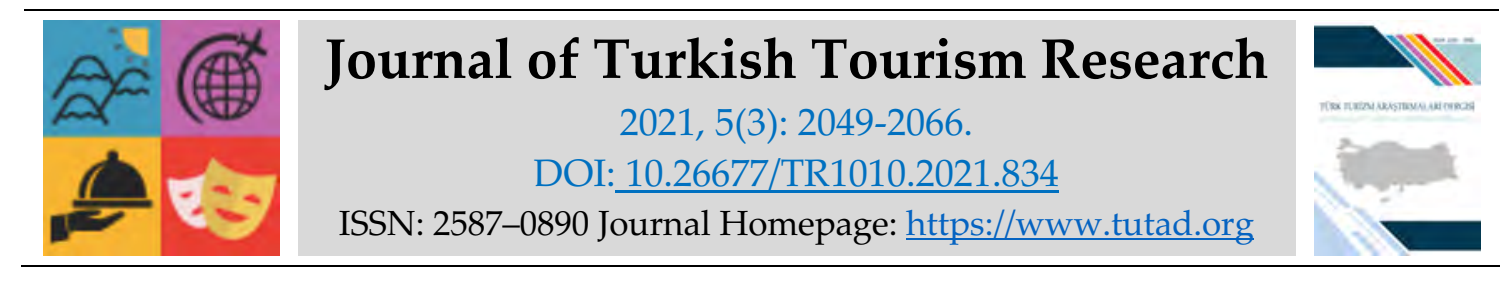

\title{
RESEARCH PAPER
}

\section{The Effect of Presenteeism on Organizational Commitment: A Research on Food- Beverage Business Perating in Adana Province}

Assistant Prof. Dr. Fatih ÖZDEMIR, İskenderun Technical University, Faculty of Tourism, Hatay, e-mail: fatih.ozdemir@iste.edu.tr ORCID: https://orcid.org/0000-0002-9087-6211

İsmail DEMİRĊ, MSc. Student, İskenderun Technical University, Graduate School of Education, Adana, e-mail: idemirci.lee@iste.edu.tr

ORCID: https://orcid.org/0000-0002-2416-1912

\begin{abstract}
Presenteeism is a negativity that occurs as a result of a person continuing her work even though she does not feel well physically or mentally. Organizational Commitment, on the other hand, can be expressed as the union of the values and interests of the organization and its employees. In this direction, in this study, it is aimed to reveal whether the presenteeism situation that the employee employed in the Food and Beverage Businesses operating in Adana has any effect on the levels of Organizational Commitment. Quantitative design was preferred in the field research and the data were collected by questionnaire technique. Frequency, reliability, factor, correlation and regression analysis techniques were used in data analysis. As a result of the analysis, no significant relationship between presenteeism and organizational commitment could be determined, but a negative and significant effect on normative commitment, which is a subdimension of organizational commitment, was determined.
\end{abstract}

Keywords: Presenteeism, Organizational Commitment, Food-Beverage Businesses, Adana.

Received: 06.05.2021

Accepted: 04.09.2021

\section{Suggested Citation:}

Özdemir, F. and Demirci, İ. (2021). The Effect of Presenteeism on Organizational Commitment: A Research on Food-Beverage Business Perating in Adana Province, Journal of Turkish Tourism Research, 5(3): 2049-2066.

(C) 2021 Türk Turizm Araştırmaları Dergisi. 


\section{Gíriş}

Firmaların geleneksel yöntemlerle varlıklarını sürdürebilmelerinin mümkün olmadığı günümüzde; artan rekabet koşulları, küreselleşme, teknolojinin ilerlemesi gibi faktörlere yani çă̆ın dinamizmine ayak uydurabildiği müddetçe firmalar hayatta kalabilmektedir. Bu dinamizmde ayak durabilmenin ana gücü işletmeyi ayakta tutan, devamlılığını sağlayan ve işletmenin mevcut durumunu iyi ya da kötü yönde etkileyecek olan işletme personelidir. Örgüt içerisinde bulunan personelin kalifiyeli, dinamik ve sağlıklı olması hiç kuşkusuz işletme yönetimini ve performansını doğrudan etkileyebilmektedir. Bu durumda örgüt içerisindeki personelin ruhen ve bedenen sağlıklı oluşu, işletmeye olumlu yönde katkı sağlayacağı aşikârdır. Özellikle üretim çıktısı hizmet olan sektörler için insan unsuru hem üreten hem de tüketen pozisyonunda olduğundan dolayı insan kaynağını etkin ve verimli bir şekilde yönetmek esastır (Seçkin ve Çakmak, 2019: 1292).

Hizmet üretiminde yoğun emek isteyen işletmelerin başında Yiyecek-İçecek İşletmeleri yer almaktadır. Yiyecek-içecek işletme personellerinin ruhsal ve fiziksel olarak sağlıklı olması, müşteri memnuniyetine sağlanacak olan katkının artmasında önemli bir rol oynamaktadır. Yoğun çalışma şartlarından kaynaklı olması gerekenden fazla iş yükü, yaptığı işten emin olamama, günlük mesai saatleri dışında kalan uzun çalışma saatleri, işleri yetiştirememe korkusu ve zaman kısıtlılığı gibi nedenler işletme personelinin ruhsal ve fiziksel sağlığını olumsuz yönde etkileyebilmektedir. (Özdemir ve Yilmaz 2019: 198). Bu olumsuzluklarla beraber personelinin veriminde yaşanacak olan düşüşün, personelin müşteriye karşı sergileyeceği davranışların olumsuzluğuna neden olacak olup bu da misafir/müşteri tatminini negatif yönde etkileyecektir.

Tek bir personelin misafire karşı sergileyeceği olumsuz durum; firma imajının zedelenmesine, pazar kaybı oluşumuna ve dolayısıyla maliyet kaybına neden olacaktır. Tam da bu noktada ortaya çıan presenteizm kavramı genel anlamıyla çalışanların ruhen ya da bedenen rahatsızlığına rağmen kendilerinde işe devam etme zorunluluğu hissetmeleri olarak tanımlanabilmektedir (Özdemir ve Yılmaz, 2019: 199).

Çalışanlar, iş yükünün fazlalığı, işten ayrılmaları durumunda boşalan kısımlarının kolaylıkla doldurulabileceği düşüncesi ve bundan kaynaklı işlerini kaybedip kariyerlerine olumsuz bir etkisi olacağı fikirlerinden dolayı işlerine dört elle sarılmakta, içerisinde bulunduğu duruma bakılmaksızın o halde sergileyeceği performansı düşünemeden işine devam edebilmektedir (Koçoğlu, 2007).

Örgütsel bağlılık, işgörenin çalıştı̆̆ işletmenin misyon ve vizyonunu benimseyerek o işletmeye olan sadakatini ortaya koyup, içerisinde bulunduğu işletmede devam etme konusunda büyük bir isteklilik/arzu gösterme durumu olarak tanımlanabilir (Randall, 1990). Örgütsel bağl1lı̆g 1 gereğinden fazla olan personel her koşulda işletmede bulunmak isteyecek ve bunun sonucunda presenteizm sorunu ile karşılaşacaktır (Turpin, Ozminkowski, Sharda, Collins, Berger, Baase, Olson ve Nicholson, 2004). Yoğun emek ve çaba isteyen hizmet sektörü içerisinde bulunan personelin herhangi bir hastalığından/yorgunluğundan kaynaklı işe devam etmesi motivasyon kaybına, iş tatminsizliğine, işten aldığı verimliliğin olumsuz yönde etkilenmesine ve dolayısıyla örgütsel performansin düşmesine neden olabilecektir.

Bu çalışmayla; Adana ilinde faaliyet gösteren yiyecek-içecek işletmelerinde istihdam edilen personellerinin sahip olduğu presenteizm algılarının örgütsel bağlılık ve alt boyutları üzerindeki etkilerinin ortaya konması amaçlanmış olup araştırma sonucu elde edilen bulguların araştırmanın gerçekleştirildiği restoran işletmelerinde istihdam edilen personellerin örgütsel 
bağlılıklarının güçlendirilmesine ve yaşayacak oldukları presenteizm'den kaynaklı problemlerin örgütsel bağlllık algıları üzerinde azaltıcı yönde etkisine neden olacağı düşünülmektedir.

\section{KAVRAMSAL ÇERÇEVE}

\section{Presenteizm}

Presenteizm, köken olarak "Presence" kelimesine dayanmaktadır. Anlam olarak "Presence" ise hazır bulunma, var olma, orada bulunma ve görünüş gibi ifadelere karşılık gelmektedir. Genel anlamıla presenteizm'in görünürde ya da fiziksel olarak var olma hali olarak ifade edilmektedir (Çiftçi, 2010). Presenteizm anlamsal bakımdan çalışanların bağlı olduğu işletmede, herhangi bir bedenen ya da ruhen rahatsızlığından dolayı istirahat etmeleri gerektiği noktada işletmedeki faaliyetlerine devam etme isteği anlamına gelmektedir (Arronson ve Gustafsson, 2005: 958). Presenteizm; çalışanların yaşadığı olumsuzluğa karşılık işletmede bulunmamaları gerekirken isteyerek ya da zorunluluk hissederek işe devam etmelerinden dolayı yaptıkları işe odaklanamamakta ve verim alamamaları sonucu ortaya çıkan olumsuz bir etkendir.

Kariyer hedefi, iş kaybetme kaygısı, işe devam etmediği günlerin maaşlarına kesinti olarak yansıma durumu yani dolayısıyla maddi kayıp düşüncesi, çalışanların işine devam etmelerini gerektiren zorunluluklardır (Rantanen ve Tuominen, 2011: 227; Yıldız ve Yıldız, 2013: 827). Presenteizmin tek nedeni çalışanların yaşadığı fizyolojik rahatsızlık olmayıp, bazen psikolojik bazen de örgüt içerisindeki herhangi bir olumsuzluktan kaynaklı durumlar olabilmektedir. Bundan dolayı herhangi bir olumsuz sağlık durumunda işte var olmama durumu değil, her türlü olumsuzluktan kaynaklı faktörler presenteizmin meydana gelmesinde etkin rol oynayabilmektedir (Baysal, Baysal, Aksu ve Aksu, 2014: 135).

Çalışanın işiyle ilgilenmesi durumunda dikkatini toparlayamayıp kendisini işine verememesinden kaynaklı farklı işlerle uğraşma isteği, presenteizmin sinyallerini vermektedir (Özmen, 2011 :18). Presenteizm ekonomik verimliliğe maliyet kaybı olarak yansıyabildiği gibi potansiyel kazancıda olumsuz yönde etkilemektedir (Sanderson, Tilse, Nicholson, Oldenburg ve Graves, 2007: 61). Tüm bu açılamalar 1şı̆̆ında presenteizm, işgörene olan etkisinin değerlendirildiğinde hem çalışanın kendisine hem de çalışma hayatına olumsuz bir etki olarak yansımaktadır (Johns, 2010). Örgütlerde karşılaşılan presenteizmden kaynaklı oluşacak olan maddi kayıplar, personelin işe gelmemesi ve personelin yaşayacağ 1 sağlik sorunu sonucu oluşacak olan maddi kayıplardan çok daha fazladır (Puig-Ribera, McKenna, Gilson ve Brown, 2008).

Verilen bilgiler ışığında maruz kalınan presenteizm sonucu oluşan sorunlar Koçoğlu (2007) tarafından 6 madde üzerinden incelenmiştir Bunlar;

Verim Düşüklülüğü: İşletme Personelinin işletme amaç ve hedefleri doğrultusunda sergilediği performansın yetersizliğine işaret etmektedir. Rekabet koşullarının artarak küresel boyuta ulaştığ1 günümüzde performansı düşük işgören, lideri tarafından olumsuz algılanacaktır. Çalışanların veriminin; dolayısıyla performansının düşmesinin en büyük nedeni ruhsal ve bedenen kendilerini iyi hissetmemeleridir. İşgöreninde böylesi bir durum hisseden/fark eden yönetici, çalışanın işletmeyle olan bağını keserek işten çıkarma uygulamak yerine bu sorunu tespit ederek çözüme kavuşturmalıdır. İşten ayrılma işgörende açacağı olumsuzluklar kadar işletmeye de negatif yönde bir etki olarak yansıyacaktır. 
Performans Düşüklüğü: Sağlığı herhangi bir yönde olumsuz etkilenen işgörenin tüm hayatı gibi iş hayatı da olumsuz yönde etkilenecek ve başarısızlık kaçınılmaz olacaktır. Herhangi bir şekilde fizyolojik ve sosyolojik rahatsızlı̆̆ bulunan personelin yapmakla ve tamamlamakla yükümlü olduğu işini yaparken tam performans sergileyemeyecektir. Çalışma performansı düşen personelin örgütsel performansa olumsuz yönde katkısı olacaktır.

Çalışan Motivasyonunda Azalma: Yöneticiler, astlarının potansiyelini, motivasyon araçlarını kullanarak ortaya çıkarmakla yükümlüdür. İşgörenin potansiyelini farkeden yöneticinin işgören üzerinde örgüte karşı sergileyeceği motivasyon ve bağlılık gibi faktörleri artırıcı etkisi olacaktır. Yüksek moral ve motivasyon ile çalışan personelin hiç kuşkusuz işletme faaliyetlerine olumlu yönde katkısı olacaktır. Yeterli tatmin düzeyine ulaşmayan moral ve motivasyona sahip işgörenin örgüte katkısından daha çok zararı olabilecektir.

Çalışan Memnuniyetsizliği: Herhangi bir olumsuzluktan kaynaklı oluşabilecek çalışan memnuniyetsizliği, personelin işe devamı hususunda olumsuzluğa, hatta işten ayrılabilmelerine sebebiyet verebilecektir. İşten ayrılan personel ayrılacak olduğu işletmeye ekstra maliyet oluşturacağından dolayı çalışan memnuniyetinin maksimize edilerek işletmeye olan bağlılığının artırılması, liderin üzerine düşen en büyük görevlerden birisidir.

İşe Devamsızlık (Absenteeizm): İşgörenin devamsızlı̆̆ına sebebiyet veren kişisel, örgütsel ve çevresel etmenler aynı zamanda presenteizme neden olan etmenleri içermektedir. Presenteizm etkilerinin artması, personelin işine devamsızlığına sebebiyet vermektedir. Dolayısıyla artan presenteizm etkisi zamanlar absenteeizm boyutuna ulaşacaktır.

İşgören Devir Hızında Artış: İşgören devir oranı yüksekliği, işletme açısından olumsuzluğun göstergesidir. İş gören devir hızı firma imajını zedeleyebileceği gibi personeller arası koordinasyonu, adaptasyonu ve istikrarı olumsuz yönde etkilenebilecektir.

Artan presenteizm etkisine maruz kalan personelde zamanla oluşan absenteeizm (işe devam problemi) bir süre sonra işgörenin işletmeden ayrılmasına neden olacaktır. Söz konusu personel ayrılmaları işgören devir hızına artırıcı yönde bir etki yapacaktır. İşgören devir hızı yüksek olan işletmelerin amaçlarına ulaşımı güçleşebileceği gibi şirket imajı da zedelenecektir.

\section{Örgütsel Bağlılık}

Örgütlerin üretimi, üretimi gerçekleştiren ve o organizasyonun parçası konumunda olan işgörenin sahip olduğu emek, bilgi ve becerilerinin işe yoğunlaştırılmasıyla gerçekleştirilir. Üretim sürecindeki ana nitelik işgörenin yeterliliğidir. Sahip olduğu yeterliliği yaptığı işe yansıtmayan personelin işletme faaliyetine herhangi bir yönde katkısı olmayacaktır. İş görenin yeterliliğinin yanında işletmeye olan sadakati ve bağlılığı da önemli bir husustur. Çalışanın sahip olduğu niteliğinin yanında örgüte olan bağlılığının da artırıcı yönde hamleler yapmak, liderlerin en büyük sorumluluklarındandır (Balay, 2000: 1-2). Artan rekabet koşullarının küresel boyuta ulaştığı günümüzde firma faaliyetlerinin devamlılığı ve örgütsel başarıya ulaşmaktaki asıl faktör işgörenlerin örgüte olan sadakatleri ve örgütsel bağlllıklarıdır. Örgütsel sadakati ve örgütsel bağlılığı yüksek olan işgörenin örgütün üretim çıtısına kalite olarak yansıyacaktır (Zaffane,1994: 978). Firmaların artan rekabet koşullarında ayakta kalabilmeleri ile işgörenlerin firmaya olan örgütsel sadakat ve örgütsel bağl1lık davranışları yakından ilgilidir. Örgütsel bağlılığın 3 temel göstergesi vardır (Mowday, Porter, ve Steers, 1982: 27). Bunlar; Örgütün misyon ve vizyonunu 
kabul etme ve sıkı sıkıya bağlanma, Örgütün vizyonuna ulaşılabilmesi için gayret gösterme, Örgütte kalma konusunda güçlü bir isteğe sahip olma şeklindedir.

Porter, Steers, Mowday ve Boulian, (1974) örgütsel bağlılığ tutum ve davranış olarak iki başlık altında irdelemişler, daha sonra Meyer ve Allen (1984)'de Porter vd., (1974) 'in ortaya koyduğu modele, duygusal ve devam bağlılığı konularını ekleyerek yeni bir model geliştirmişlerdir (Ağırbaş ve Yıldızhan, 2019: 1296).

Duygusal Bağlllık: İşgörenin içerisinde bulunduğu işletmenin amaç ve hedeflerine bağlllı̆̆ını ve bu hedeflere ulaşmadaki faaliyetlerinde olağanüstü güç sergilemesini ifade etmektedir. Bu sebepten dolayı duygusal bağlılık örgütler açısından oldukça önemsenen bir bağlılık türüdür (Mowday, 1998).

Devam Bağlılığı: Örgüte yapılan yatırımlar, harcanan emek, örgütte geçirilen zaman gibi durumlar, işgöreni işletmede tutan faktörlerin başında gelmektedir. Bundan dolayı işgörenin örgütte harcayacağı zaman, emek ve örgüte yapacağı yatırımın miktarı arttıkça, işgörenin işletmeye olan bağlılığında da artırıcı yönde bir etki olacaktır (Allen ve Meyer, 1990).

Normatif Bağlllık: İşgörenin kendisi örgüte karşı sorumlu hissetmesini ve bundan dolayı işletmede devam etmesi gerektiği yönünde zorundalık haline girmesini ifade etmektedir. İşgören, içerisinde bulunduğu örgütün kendisine çok büyük katkıları olduğunu düşünerek kendisini işletmeye karşı borçlu hisseder ve bağlılık göstermeyi görev olarak benimser (Çetin, 2004). Normatif Bağlılık maddiyattan daha çok erdem ve ahlaki davranışların etkisiyle gösterilen bir bağlllık türüdür (Gül, 2002).

\section{Presenteizm ve Örgütsel Bağlılık}

Presenteizm, işgören üzerinde oluşan rahatsızlığına rağmen işine devam etmesi olarak tanımlanabilir. Yaşadığı rahatsızlığa rağmen işine devam etmekte olan personelin işletme yararına herhangi bir performans gösteremeyeceği gibi yaşanacak olan olumsuzlukların doğurduğu sonuç olarak bu durum çalışanın işe devamsızlık durumu yaşamasına ve bunun neticesinde Örgüte karşı beslenen Bağlılık duygularının koparak işten ayrılmalara sebebiyet vereceği düşünülmektedir.

Herhangi bir rahatsızlı̆̆ına rağmen yaptığı işe devam etmekte olan örgüt içerisinde diğer personelleri de olumsuz yönde etkileyecek ve bu durumun da örgütün tamamının örgüte olan bağlılı̆̆ını olumsuz yönde etkileyecektir.

Presenteizmin sağlık üzerinde yarattığı olumsuz etkilerin yanı sıra ekonomik olarak ta olumsuz sonuçlar doğurdu anlaşılmaktadır (Janssens, Clays, Clerqo, Bacquer, Casini ve Braeckman, 2016: 332). Kişinin fiziken ya da ruhen hasta olmasına rağmen işe devam etmesi, içerisinde bulunduğu sağlık durumunun rahatsızlığının büyümesine neden olacağı gibi yaptığı/faaliyet gösterdiği işin kalitesi de olumsuz yönde etkilenecektir (Kim, Suh, Ju, Choo, Bae ve Choi, 2016: 32). Rahatsızlıktan dolayı işe devam edilmesi çalışan yetersizliğini ortaya çıkaracak ve bu durum da azalan verimliliği ve örgütsel bağl1lı̆̆ beraberinde getirecektir (Johns, 2010: 521).

Herhangi bir rahatsızlığına rağmen işe devam etmekte olan personelin performans düşüklüğü, içerisinde bulunduğu rahatsızlığı diğer çalışanlara bulaştırma ihtimali, iş yerindeki moral ve motivasyonun düşmesine, dolayısıyla örgütsel performansa olumsuz yönde etki yapacağından 
dolayı bu personellerin işe gelmeyip evlerinde dinlenmelerini hem kendi sağlıkları açısından hemde işletme sağlı̆̆ı açısından büyük önem arz etmektedir (Monojit ve Tilley, 2002).

Genel anlamda güncel olan Presenteizm ve Örgütsel Bağlllık konusu Şahin (2016), Kaygın, Kerse ve Yılmaz (2017), Erbaş (2017) ve Özmen (2011) tarafından ele alınmıştır. Kaygın vd., (2017) ve Şahin (2016) yaptıkları çalışmalarda çalışanların örgütsel bağlılık düzeyleri ile yaşadıkları presenteizm durumu arasında anlamlı bir ilişki olduğunu ortaya koyarken Erbaş (2017) yaptığı çalışmada örgütsel bağlılı̆̆ın boyutlarından olan duygusal bağlılık boyutunun presenteizm durumu üzerinde etkisi olduğunu ortaya koymuştur. Özmen (2011) ise presenteizm durumunun örgütsel bağlılı̆̆ın alt boyutlarından duygusal ve normatif bağlllık boyutları arasında ilişki olduğunu ortaya koymuştur.

\section{ARAŞTIRMA YÖNTEMI}

Presenteizm ve Örgütsel Bağlllık ilişkisini inceleyen çalışmalardan hareketle, yiyecek-içecek İşletmesi çalışanlarının presenteizm algılarının örgütsel bağlılıkları düzeyleri üzerindeki etkisini ölçen bu çalışmada daha önce ortaya konan çalışma sonuçlarından farklı olarak negatif yönde ilişki olacağı öngörülmüştür. İlgili Öngörü paralelinde Presenteizmden kaynaklanan olumsuz sonuçların örgütsel bağlılık üzerinde negatif yönde etkisinin olabileceğine yönelik aşağıda yer verilen H1 Hipotezi ve Örgütsel Bağlılı̆̆ın Alt boyutlarına bağlı olarak alt hipotezler geliştirilmiştir. Araştırmanın grafiksel modeli Şekil 1'de sunulmaktadır.

Şekil 1: Araştırmanın grafiksel modeli

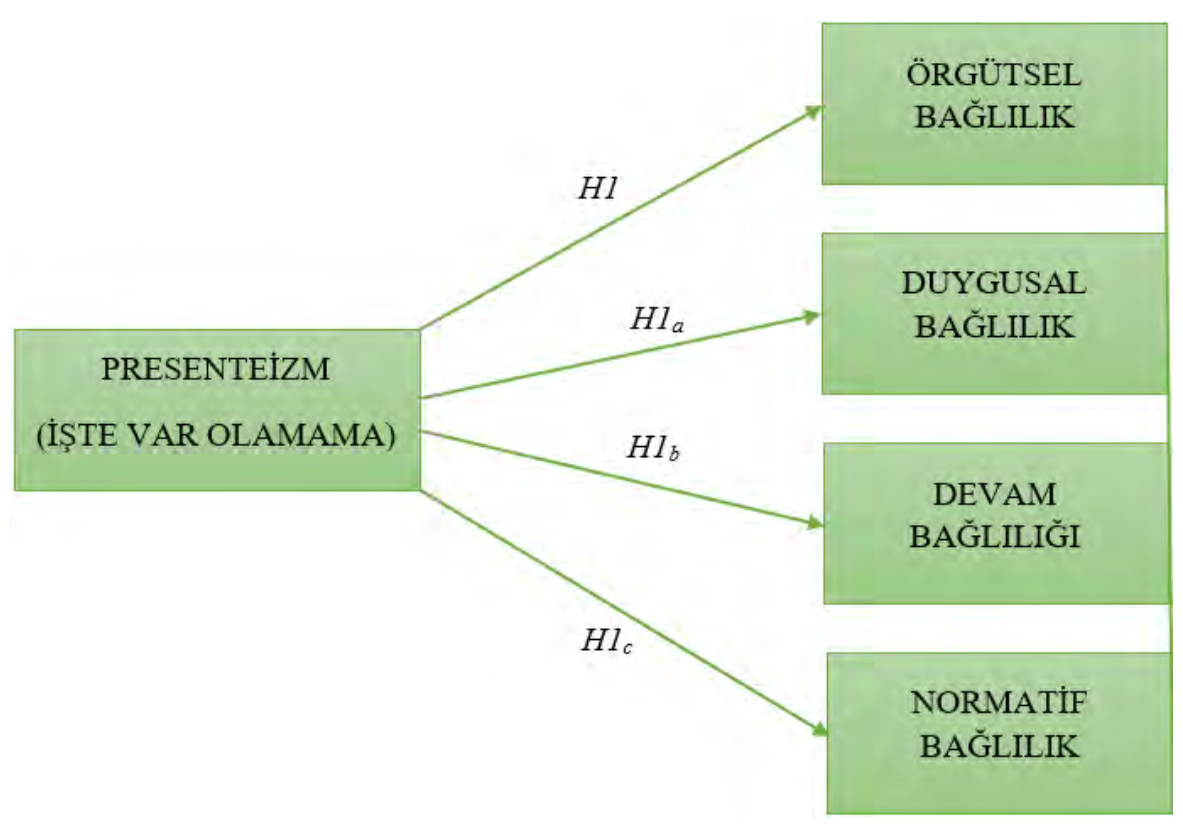

H1: İşgörenin yaşadığı Presenteizm Durumunun Örgütsel Bağlılık üzerinde negatif ve anlamlı yönde bir etkisi vardır.

H1a: İşgörenin yaşadığı Presenteizm Durumunun Duygusal Bağlılık üzerinde negatif ve anlamlı yönde bir etkisi vardır.

H1b: İşgörenin yaşadığı Presenteizm Durumunun Devam Bağlılığı üzerinde negatif ve anlamlı yönde bir etkisi vardır. 
H1،: İşgörenin yaşadığı Presenteizm Durumunun Normatif Bağlılık üzerinde negatif ve anlamlı yönde bir etkisi vardır.

Araştırma verilerinin toplanmasında nicel araştırma deseni benimsenmiştir. Veri toplamada, çalışanların presenteizm algılarının örgütsel bağllıklarına olan etkisinin ortaya konması amacıyla anket tekniği kullanılmıştır.

Anket çalışmasının ilk kısmında katılımcıların cinsiyet, yaş ve eğitim durumunu belirlemeye yönelik demografik özelliklere ait bilgilere yer verilmiştir. Araştırma da kullanılan anketin birinci ölçeğini Koopman vd., (2002) tarafından geliştirilip Coşkun (2012) tarafından Türkçeye uyarlanan ve Kendir, Arslan ve Özçelik Bozkurt (2018)' nin çalışmasında kullandığı iki boyuttan ve altı ifadeden oluşan "Standford Presenteizm Ölçeği (SPS 6)" kullanılmıştır.

Araştırma verilerinin toplanmasında kullanılan ikinci ölçek ise Meyer ve Allen (1991) tarafından geliştirilip Kaya ve Selçuk (2007) tarafından Türkçe'ye uyarlanan Örgütsel Bağlllık Ölçeğidir. Örgütsel Bağllıı Ölçeği; Duygusal Bağlllık Ölçeği, Devam Bağlılığı ve Normatif Bağlllık olmak üzere 3 boyuttan ve 18 maddeden oluşmaktadır.

Her iki ölçeğin değerlendirilmesinde "Kesinlikle Katılmıyorum, Katılmıyorum, Orta Düzeyde Katılıyorum ve Kesinlikle Katılıyorum" şeklinde 5'li Likert ölçeği kullanılmıştır.

Anket çalışması İskenderun Teknik Üniversitesi Bilimsel Araştırma ve Yayın Etiği kurulunun 30.03.2021 tarihli ve E.7723 sayılı kararına göre 15.04.2021-01.06.2021 tarihleri arasında Adana İlinde faaliyet gösteren yiyecek-içecek çalışanları üzerine uygulanmıştır. Adana'da yiyecekiçecek sektöründe 2348 işletme faaliyet göstermekte ve bu işletmelerde 11834 çalışan istihdam edilmektedir (SGK, 2019). Araştırma evrenini Adana İlinde yer alan tüm yiyecek-içecek sektöründe faaliyet gösteren işletmeler olmasına karşılık araştırma örneklemini merkez ilçesinde yer alan yiyecek-içecek işletmeleri oluşturmaktadır. Araştırma COVID-19 Pandemi döneminde uygulandığından dolayı sınırlı sayıda açık olan işletmeler ve bu işletmelerde istihdam edilen 150 ayrı personel üzerine uygulanmıştır. Pandemi döneminde açık olan işletmelerin sayısı ve bu işletmelerde çalışan personel sayısına ulaşılamadığından dolayı evren sonsuz kabul edilmiş ve bu durumda kullanılan formülden hareketle örneklem büyüklüğü 0,90 güven düzeyine (\%90 güven aralığı) ve \pm 10 örnekleme hatasına göre hesaplanmış olup araştırmaya 96 kişinin katılımının uygun olduğu anlaşılmıştır (Yazıcıŏglu ve Erdoğan, 2004: 50). Rastgele ve tamamını 1-5 seçeneklerini işaretleyen kişilerin yer aldığ 130 anket analiz sürecine dahil edilmemiş ve analiz sürecine 120 anket sonucu ile devam edilmiştir.

\section{BULGULAR}

Araştırmaya dahil olan 120 kişiye ait elde edilen demografik veriler Tablo 1'de ifade edilmektedir. Tablo 1.'de yer alan değerlere göre araştırmaya katılım sağlayan kişilerin $\% 60^{\prime} 1$ 'Erkek' ve \%40' 1 'Kadın' cinsiyetine sahiptir. Katılım sağlayan kişilerin \%34'ü '25 yaş ve altı' yaşa sahip olduklarını belirtirken \%23'ü '26-30 yaş', \%20'si '31-35 yaş', \%13'ü '36-40 yaş', \%7'si ‘41-45 yaş' ve \%3'ü ‘46 ve üzeri' yaş grubuna dahil olduklarını belirtmişlerdir. "Medeni durumunuz" sorusuna katılımcıların $\% 55$ 'i ‘Bekar' yanıtını verirken geriye kalan $\% 45$ ' $\mathrm{i}$ ‘Evli' yanıtını vermişstir. 
Tablo 1. Katılımcılara İlişkin Demografik Özelliklerin Dağılımı

\begin{tabular}{|c|c|c|c|c|c|c|c|}
\hline & $\begin{array}{l}\text { Demografik } \\
\text { Değişkenler }\end{array}$ & n (120) & $\%$ & & $\begin{array}{l}\text { Demografik } \\
\text { Değişkenler }\end{array}$ & n (120) & $\%$ \\
\hline \multirow{2}{*}{ Cinsiyet } & Kadın & 48 & 40 & \multirow{7}{*}{$\begin{array}{c}\text { İşletmedeki } \\
\text { Pozisyon }\end{array}$} & $\begin{array}{c}\text { Servis } \\
\text { Personeli }\end{array}$ & 46 & 38 \\
\hline & Erkek & 72 & 60 & & $\begin{array}{l}\text { Temizlik } \\
\text { Personeli }\end{array}$ & 30 & 25 \\
\hline \multirow{6}{*}{ Yaş } & 25 ve altı & 41 & 34 & & $\begin{array}{l}\text { Yönetim } \\
\text { Kademe } \\
\text { Personeli }\end{array}$ & 14 & 12 \\
\hline & 26-30 yaş & 27 & 23 & & Kasiyer & 17 & 14 \\
\hline & 31-35 yaş & 24 & 20 & & Güvenlik & 4 & 3 \\
\hline & $36-40$ yaş & 16 & 13 & & $\begin{array}{c}\text { Teknik } \\
\text { Personeli }\end{array}$ & 4 & 3 \\
\hline & $41-45$ yaş & 8 & 7 & & Diğer & 5 & 5 \\
\hline & 46 ve üzeri & 4 & 3 & \multirow{5}{*}{$\begin{array}{l}\text { İşletmede } \\
\text { Çalışma } \\
\text { Süresi }\end{array}$} & 5 yıl ve altı & 41 & 34 \\
\hline & Bekar & 66 & 55 & & 6-10 yil arası & 36 & 30 \\
\hline Durum & Evli & 54 & 45 & & $\begin{array}{c}\text { 11-15 y1l } \\
\text { arası }\end{array}$ & 32 & 27 \\
\hline \multirow{7}{*}{$\begin{array}{l}\text { Eğitim } \\
\text { Durumu }\end{array}$} & İlkokul & 34 & 28 & & $\begin{array}{c}\text { 16-20 y1l } \\
\text { arası }\end{array}$ & 10 & 8 \\
\hline & Lise & 39 & 32 & & $\begin{array}{c}\text { 21-25 yıl } \\
\text { arası }\end{array}$ & 1 & 1 \\
\hline & Ön Lisans & 27 & 23 & \multirow{5}{*}{$\begin{array}{c}\text { Mevcut } \\
\text { Pozisyonda } \\
\text { Çalışma } \\
\text { Süresi }\end{array}$} & 5 yil ve altı & 48 & 40 \\
\hline & Lisans & 17 & 14 & & 6-10 yıl arası & 44 & 37 \\
\hline & Lisansüstü & 3 & 3 & & $\begin{array}{c}\text { 11-15 yıl } \\
\text { arası }\end{array}$ & 18 & 15 \\
\hline & & & & & $\begin{array}{c}\text { 16-20 yıl } \\
\text { arası }\end{array}$ & 8 & 7 \\
\hline & & & & & $\begin{array}{c}\text { 21-25 yıl } \\
\text { arası }\end{array}$ & 2 & 1 \\
\hline
\end{tabular}

Katılımcıların eğitim durumlarını belirlemeye yönelik kendilerine yöneltilen "Eğitim Durumunuz" sorusuna ise katılımciların \%28'i 'illkokul' \%32'si ‘Lise', \%23'ü ‘Ön Lisans', \%14'ü 'Lisans' ve \%3'ü 'Lisansüstü' yanıtını vermiştir. "İşletmedeki Pozisyonunuz" sorusuna ise katılımcların \%38'lik kısmı 'Servis Personeli', \%25'lik kısmı 'Temizlik Personeli', \%12'lik kısmı 'Yönetim Kademe Personeli' \%14'lük kısmı 'Kasiyer', \%3'lük kısmı 'Güvenlik', \%3'lük kısmı 'Teknik Personeli' ve geriye kalan \%5'lik kısımlık kesim ise çalıştıkları işletmede ölçekte yer almayan farklı bir pozisyonda çalıştıklarını belirtmişlerdir. Bulundukları işletmedeki çalışma sürelerine yönelik kendilerine yöneltilen "İşletmede Çalışma Süresi" sorusuna ise katılımcıların

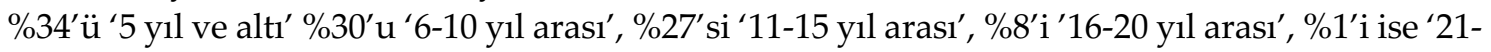
25 yıl arası' yanıtını vermiş̧ir. Bulundukları pozisyonda ne kadar süredir çalıştıklarını 
belirlemeye yönelik kendilerine yöneltilen "Mevcut Pozisyonda Çalışma Süresi" sorusuna ise katılımciların \%40'1 '5 yıl ve altı', \%37'si '6-10 yıl arasi', \%15'i '11-15 yıl arasi', \%7'si '16-20 yıl arası', \%1'i ise '21-25 yıl arası' yanıtını vermiştir.

Araştırmada yararlanılan "Presenteizm" ve "Örgütsel Bağlılık" Ölçeklerinin yapısal geçerliliğini belirlemek amacıyla keşfedici faktör analizi uygulanmıştır. Her iki ölçeğin faktör öz değerlerinin 1'in üzerinde olması faktör analizi öncesi varsayım olarak ifade edilmiştir. Döndürme yöntemi olarak Varimax yöntemi kullanılmıştır. Her bir ölçeğe ait faktör analizi sonuçları, ölçek maddelerine ilişkin ortalama, standart sapma ve güvenilirlik (Cronbach's Alpha) değerleri Tablo 2. ve Tablo $3^{\prime}$ te ifade edilmektedir.

Tablo 2. Presenteizm Ölçeğine İlişkin Faktör Analizi

\begin{tabular}{|c|c|c|c|c|}
\hline Ölçek Maddesi & $\begin{array}{c}\text { Faktör } 1 \\
\text { "İşi } \\
\text { Tamamlayamama" }\end{array}$ & $\begin{array}{c}\text { Faktör } 2 \\
\text { “Dikkat } \\
\text { Dağınıklığından } \\
\text { Kaçınamama" }\end{array}$ & Ort. & $\begin{array}{l}\text { Std. } \\
\text { Sapma }\end{array}$ \\
\hline $\begin{array}{l}\text { 3. Eğer hastalanırsam, zor durumda } \\
\text { olmama rağmen tüm işlerimi } \\
\text { tamamlayabilecek kadar kendimi } \\
\text { enerjik hissederim. (R) }\end{array}$ &, 850 & \multirow{3}{*}{-} & 1,58 & 0,82 \\
\hline $\begin{array}{l}\text { 1. Eğer hastalanırsam, zor durumda } \\
\text { olmama rağmen işimdeki zor } \\
\text { görevleri tamamlayabilirim. (R) }\end{array}$ & ,845 & & 1,44 & 0,75 \\
\hline $\begin{array}{l}\text { 2. Eğer hastalanırsam, zor durumda } \\
\text { olmama rağmen görevlerimi yerine } \\
\text { getirmeye odaklanabilirim. (R) }\end{array}$ & 812 & & 1,49 & 0,77 \\
\hline $\begin{array}{l}\text { 5. Eğer hastalanırsam, işimi } \\
\text { yapmaktan zevk almam. }\end{array}$ & \multirow{3}{*}{-} & 800 & 4,33 & 0,83 \\
\hline $\begin{array}{l}\text { 6. Ĕger hastalanırsam, görevimi } \\
\text { tamamlama konusunda } \\
\text { umutsuzluğa kapılabilirim. }\end{array}$ & & 753 & 4,53 & 0,75 \\
\hline $\begin{array}{l}\text { 4. Eğer hastalanırsam, iş stresiyle } \\
\text { başa çıkmakta zorlanırım. }\end{array}$ & & 640 & 4,42 & 0,70 \\
\hline Özdeğerler (eigenvalues) & 2,12 & 1,64 & & \multirow{7}{*}{ - } \\
\hline Açıklanan Varyans & $\% 35,42$ & $\% 27,34$ & & \\
\hline \multirow{2}{*}{ Ölçek Güvenilirliği } & ,792 &, 582 & & \\
\hline & \multicolumn{2}{|c|}{ 668 } & & \\
\hline \multirow{2}{*}{ Ortalama } & 1,50 & 4,43 & & \\
\hline & \multicolumn{2}{|c|}{2,96} & & \\
\hline Açıklanan Toplam Varyans & \multicolumn{2}{|c|}{$\% 62,761$} & & \\
\hline \multicolumn{5}{|c|}{$\begin{array}{l}\text { Kaiser-Meyer-Olkin örneklem uygunluk ölçümü= ,705; } \\
\text { Bartlett'in Küresellik Testi: X2 =,145,072; s.d=,15; p<0,001 }\end{array}$} \\
\hline
\end{tabular}

Not: $(R)$ ile gösterilen ifadeler tersten kodlanmıştır. 
İki faktör olarak oluşan ve varyansının \%62,76 açklayan faktör boyutunun belirlenmesi ile "Presenteizm" ölçeğinin yeterli bir ölçek olduğu ifade edilmektedir. Analize dahil edilen değişkenlerin toplam varyansın 2/3'ü kadar miktarının açıklanması, yüksek düzeyde bir açılayıcılık olarak değerlendirilmektedir (Çokluk, Şekercioğlu ve Büyüköztürk, 2012: 197). Ölçek güvenilirlik düzeyine (Cronbach's Alpha) bakıldığında ise ölçeğin genelinin güvenilirlik değeri ,668 iken "İşi Tamamlayamama" boyutunun güvenilirlik değeri ,792 ve "Dikkat Dağınıklılığından Kaçınamama" boyutunun güvenilirlik değeri ,582 olarak tespit edilmiştir. Özdamar (2002: 667) ve Tavşancıl'a (2002) göre Cronbach's Alpha katsayısının 0.40 değerinin altında olması güvenilir olmadığını, 0.40-0.50 değeri arasında olması düşük güvenilirliğe, 0,600,79 değeri arası oldukça güvenilir, 0,80-1,00 düzeyleri arasında ifade edilen değerler ise yüksek derecede güvenilir olduğunu ifade etmektedir. Verilen referanslar ışığında ölçeğe ait her iki alt boyutunun ve ölçek ana boyutunun güvenilirlik değerlerinin kabul edilebilir bir seviyede olduğunu söylemek mümkündür (Cronbach's Alfa $\geq 0.40$ ). Örneklem yeterliliğinin veri yapısı açısından uygunluğunun ölçütü olan Kaiser-Mayer-Olkin (KMO) ve Çok değişkenli bir yapıya sahip olunup olunmadığının belirlenmesine yarayan Barlett Küresellik testleri uygulanmıştır (Çokluk vd., 2012: 219). Faktör analizinin gerçekleştirilebilmesi için KMO değerinin 0,50'den yüksek ve Barlett test sonucunun anlamlı olarak bulunması gerekmektedir (Kalayc1, 2010: 321). "Presenteizm" ölçeğine ilişkin elde edilen KMO değeri ,705, Barlett test sonucu ise anlamlı bir düzeyde bulunmuştur $(\mathrm{p}<0.001)$.

Örgütsel Bağlılık ölçeği, daha önce yapı geçerliliği sınanmış bir ölçek olması nedeniyle her bir boyutunun yapı geçerliliğini sağlamak adına ayrı ayrı faktör analizi yapılmıştır. Faktör analizi sonucu elde edilen bulgular Tablo 3 'te ifade edilmektedir.

Tablo 3'te ifade edilen faktör boyutlarına ilişkin toplam açıklanan varyans oranlarından hareketle açıklanma düzeylerinin \%45,35 ile \%68,25 aralı̆̆ında olduğunu söylemek mümkündür. Bu değerler "Örgütsel Bağlllık" ölçeğinin yeterli bir ölçek olduğunu ifade etmektedir. Boyutlara ilişkin KMO değerlerinin ,783 ile ,868 yer alması ölçeğin örneklem yeterliliği açısından uygunluğunu ortaya koymaktadır. Boyutların Bartlett küresellik testi sonucu ise istatistiksel olarak anlamlı bulunmuştur ( $\mathrm{p}<0.001)$. Ölçek genelinin $(, 905)$ ve alt boyutlarının $(, 750-906)$ güvenilirlik değerine bakıldığında ise ölçeğin genelinin ve boyutlarının güvenilirlik düzeylerinin kabul edilebilir bir seviyede olduğunu belirtmek mümkündür (Cronbach's Alfa $\geq 0.40$ ) (Mooi ve Sarstedt 2011: 221; Özdamar 2011: 605).

Bağımlı ve bağımsız değişkenler arasında ilişkiyi belirlemek adına korelasyon analizi yapılmıştır. Elde edilen değerlerle birlikte değişkenlere ilişkin ortalama ve standart sapma değerleri Tablo 4 'te ifade edilmektedir. 
Tablo 3. Örgütsel Bağlllık Ölçeğine İlişkin Faktör Analizi Sonucu

\begin{tabular}{|c|c|c|c|c|c|}
\hline Ölçek Maddesi & $\begin{array}{l}\text { Faktör } 1 \\
\text { “Duygusal } \\
\text { Bağlılık" }\end{array}$ & $\begin{array}{l}\text { Faktör } 2 \\
\text { "Devam } \\
\text { Bağlılığı" }\end{array}$ & $\begin{array}{c}\text { Faktör } 3 \\
\text { “Normatif } \\
\text { Bağlılık" }\end{array}$ & Ort. & $\begin{array}{l}\text { Std. } \\
\text { Sapma }\end{array}$ \\
\hline 10. İşyerime karşı duygusal bir bağ hissederim. &, 872 & \multirow{6}{*}{ 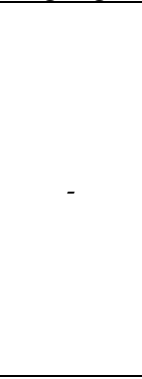 } & \multirow{6}{*}{ 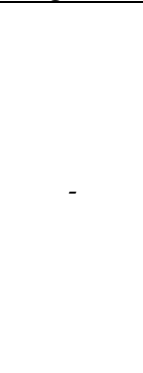 } & 4,27 & 1,11 \\
\hline $\begin{array}{l}\text { 12. İşyerime karşı güçlü bir aitlik duygusu } \\
\text { hissederim. }\end{array}$ &, 847 & & & 4,28 & 1,07 \\
\hline $\begin{array}{l}\text { 8. İşyerimin sorunlarını kendi sorunlarım gibi } \\
\text { hissederim. }\end{array}$ &, 841 & & & 4,22 & 1,11 \\
\hline $\begin{array}{l}\text { 9. İsyyerimde kendimi "ailenin bir parçası" olarak } \\
\text { hissederim. }\end{array}$ & 828 & & & 4,19 & 1,16 \\
\hline 11. İşyerim benim için özel bir anlam taşır. & ,822 & & & 4,31 & 1,02 \\
\hline $\begin{array}{l}\text { 7. Kariyerimin geri kalanını bu organizasyonda } \\
\text { geçirmekten mutluluk duyarım. }\end{array}$ & ,741 & & & 4,25 & 1,07 \\
\hline $\begin{array}{l}\text { 14. Şu an işyerimden ayrılmak istediğime karar } \\
\text { verirsem hayatımın büyük bölümü olumsuz } \\
\text { etkilenir. }\end{array}$ & \multirow{6}{*}{-} & ,796 & \multirow{6}{*}{-} & 4,24 & 1,20 \\
\hline $\begin{array}{l}\text { 16. İşyerimden ayrılmayı düşünmek için çok az } \\
\text { seçeneğim olduğunu düşünüyorum. }\end{array}$ & & ,765 & & 4,05 & 1,19 \\
\hline $\begin{array}{l}\text { 17. İşyerimden ayrılmama nedenlerimden biri de } \\
\text { olası işyeri alternatiflerin azlığıdır. }\end{array}$ & & ,663 & & 4,18 & 1,12 \\
\hline $\begin{array}{l}\text { 15. Şu an işyerimde kalmam, bir istek olduğu } \\
\text { kadar gerekliliktir. }\end{array}$ & & ,649 & & 4,30 & 0,99 \\
\hline $\begin{array}{l}\text { 13. İstesem bile şu an işyerimden ayrılmak benim } \\
\text { için çok zor olurdu. }\end{array}$ & &, 583 & & 4,30 & 1,24 \\
\hline $\begin{array}{l}\text { 18. İşsyerime bu kadar katkım olmasaydı, başka } \\
\text { bir yerde çalışmayı düşünebilirdim. }\end{array}$ & &, 550 & & 3,85 & 1,28 \\
\hline $\begin{array}{l}\text { 23. İşyerimdeki sorumluluklarım nedeniyle işten } \\
\text { ayrılmamın doğru olmayacağını düşünüyorum. }\end{array}$ & \multirow{6}{*}{-} & \multirow{6}{*}{ - } & ,794 & 4,27 & 1,11 \\
\hline 22. İşyerim benim bağlılığımı hak ediyor. & & &, 770 & 4,27 & 1,02 \\
\hline $\begin{array}{l}\text { 24. Kariyer gelişimim açısından işyerime çok şey } \\
\text { borçluyum. }\end{array}$ & & & 767 & 4,50 & 1,00 \\
\hline $\begin{array}{l}\text { 21. İşyerimden şimdi ayrılsam suçluluk } \\
\text { hissederim. }\end{array}$ & & & ,744 & 4,13 & 1,24 \\
\hline $\begin{array}{l}\text { 20. Benim için avantajlı olsa bile, işyerimden } \\
\text { şimdi ayrılmak bana doğru gelmiyor. }\end{array}$ & & & ,667 & 3,78 & 1,32 \\
\hline $\begin{array}{l}\text { 19. İşyerimde çalışmaya devam etmek için } \\
\text { kendimi zorunlu hissederim. }\end{array}$ & & &, 529 & 3,82 & 1,28 \\
\hline Özdeğerler (eigenvalues) & 4,095 & 2,721 & 3,090 & & \multirow{11}{*}{-} \\
\hline Açıklanan Varyans & $\% 68,25$ & $\% 45,35$ & $\% 51,50$ & & \\
\hline \multirow[t]{2}{*}{ Ölçek Güvenilirliği } & ,906 &, 750 &, 800 & & \\
\hline & \multicolumn{3}{|c|}{,905 } & & \\
\hline \multirow[b]{2}{*}{ Ortalama } & 4,25 & 4,15 & 4,13 & & \\
\hline & \multicolumn{3}{|c|}{4,18} & & \\
\hline Açıklanan Toplam Varyans & $\% 68,25$ & $\% 45,35$ & $\% 51,50$ & & \\
\hline KMO Değeri & 868 & ,783 & 792 & & \\
\hline Barlet'in Küresellik Testi & 446,854 & 158,779 & 242,620 & & \\
\hline Sabit Değer & 15 & 15 & 15 & & \\
\hline \multicolumn{4}{|c|}{$\mathrm{p}<0,001$} & & \\
\hline
\end{tabular}

Araştırmanın gerçekleştirildiği işletmelerde istihdam edilen personelin ölçek maddelerine vermiş olduğu yanıtlardan hareketle Örgütsel Bağlllık ve Presenteizm ölçeklerinin ortalama ve standart sapma değerleri oluşturulmuş ve Tablo 4'te yer verilmiştir. Kaygın, Kerse ve Yılmaz (2017)' a göre ölçek ana ve alt boyutlarının ortalaması 1- 1,79 arasında yer alıyorsa çok düşük; 1,80 - 2,59 aralığında yer alıyorsa düşük; 2,60 - 3,39 ortalama arasında yer alıyorsa orta; 3,40 4,19 değer aralığında ise yüksek; 4,20 -5.00 değer aralığında ise çok yüksektir. 
Tablo 4. Değişkenlere İlişkin Ortalama, Standart Sapma ve Korelasyon Analizi Değerleri

\begin{tabular}{|c|c|c|c|c|c|c|c|}
\hline $\begin{array}{c}\text { Değişkenler } \\
(\mathrm{n}=120)\end{array}$ & Ortalama(x) & $\begin{array}{c}\text { Std. } \\
\text { Sapma }\end{array}$ & Presenteizm & $\begin{array}{l}\text { Örgütsel } \\
\text { Bağlılık }\end{array}$ & $\begin{array}{c}\text { Duygusal } \\
\text { Bağlılık }\end{array}$ & $\begin{array}{l}\text { Devam } \\
\text { Bağlılığı }\end{array}$ & $\begin{array}{c}\text { Normatif } \\
\text { Bağlılık }\end{array}$ \\
\hline Presenteizm & 2,96 & 0,47 & 1 & & & & \\
\hline $\begin{array}{l}\text { Örgütsel } \\
\text { Bağlılık }\end{array}$ & 4,18 & 0,71 & $\begin{array}{c}-, 113 \\
, 220\end{array}$ & 1 & & & \\
\hline $\begin{array}{l}\text { Duygusal } \\
\text { Bağlılık }\end{array}$ & 4,25 & 0,90 & $\begin{array}{l}-, 108 \\
, 239\end{array}$ & $\begin{array}{l}, 844^{* *} \\
, 000\end{array}$ & 1 & & \\
\hline $\begin{array}{l}\text { Devam } \\
\text { Bağlılığ1 }\end{array}$ & 4,15 & 0,78 & $\begin{array}{l}, 022 \\
, 809\end{array}$ & $\begin{array}{l}, 832^{* *} \\
, 000\end{array}$ & $\begin{array}{l}, 523^{* *} \\
, 000\end{array}$ & 1 & \\
\hline $\begin{array}{l}\text { Normatif } \\
\text { Bağlilık }\end{array}$ & 4,13 & 0,83 & $\begin{array}{l}-, 194^{*} \\
, 034\end{array}$ & $\begin{array}{l}, 867^{* *} \\
, 000\end{array}$ & $\begin{array}{l}, 588^{* *} \\
, 000\end{array}$ & $\begin{array}{l}, 624^{* *} \\
, 000\end{array}$ & 1 \\
\hline${ }^{* *} \mathrm{p}<0,01{ }^{*} \mathrm{p}$ & & & & & & & \\
\hline
\end{tabular}

Katılımcıların 'Presenteizm' ölçeğine ilişkin verdikleri yanıtın ortalaması $(2,96)$ 'orta düzeyde' olduğunu gösterirken; 'Normatif Bağlllık' $(4,13)$ ve 'Devam Bağlılı̆̆g' $(4,15)$ ölçeğine ilişkin verilen yanıtların ortalaması 'yüksek düzeyde' olduğu belirlenmiş olup 'Duygusal Bağlllık' $(4,25)$ için 'Çok yüksek' ortalamaya sahip olduğu tespit edilmiştir. Ayrıca 'Örgütsel Bağlllık' ölçeğinin ana boyut olarak $(4,18)$ 'yüksek' düzeyde bir ortalamaya sahip olduğu tespit edilmiştir.

Değişkenler arası oluşan korelasyon değerleri ve anlamlılık düzeyleri Tablo 4'te ifade edilmektedir. Kalaycı (2010)'ya göre korelasyon katsayı değeri 0,00-0,25 aralığında ise ilişki "çok zayıf", 0,26-0,49 aralığında "zayıf", 0,50-0,69 aralığında "orta", 0,70-0,89 aralığında "yüksek" ve 0,90-1,00 aralığında ise "çok yüksek" bir ilişki olduğunu belirtmektedir. Presenteizm ile örgütsel bağlılık, duygusal bağlllık ve devam bağlllığı arasında herhangi bir anlamlı ilişki tespit edilemezken örgütsel bağlılığın alt boyutu olan normatif bağlılık ile arasında düşük düzeyde ve negatif yönde olumsuz bir ilişki tespit edilmiştir ( $r=,-194 \mathrm{p}<0,05)$.

Anlamlı bir ilişki tespit edilememesinden dolayı, $\mathbf{H}_{1}$ : “İşgörenin yaşadığı Presenteizm Durumunun Örgütsel Bağlılık üzerinde negatif ve anlamlı yönde bir etkisi vardır." hipotezi,

$H_{1 a:}$ "İşgörenin yaşadığı Presenteizm Durumunun Duygusal Bağlılık üzerinde negatif ve anlamlı yönde bir etkisi vardır." hipotezi ve $\mathbf{H}_{1 b}$ : "İşgörenin yaşadığı Presenteizm Durumunun Devam Bağlılığı üzerinde negatif ve anlamlı yönde bir etkisi vardır." hipotezi kabul edilmemiştir.

Anlamlılık ilişkisi tespit edilen $\mathbf{H}_{11}$ : "İşgörenin yaşadığı Presenteizm Durumunun Normatif Bağlılık üzerinde negatif ve anlamlı yönde bir etkisi vardır." hipotezini test etmek için basit doğrusal regresyon analizi uygulanmıştır. Elde edilen değer aşağıda yer alan Tablo 5 'te ifade edilmektedir.

Gerçekleştirilen regresyon analizi sonrası bağımlı değişkene ilişkin (Normatif Bağlllık) toplam varyansın \%0,29'u Presenteizm ile açıklanmaktadır (Büyüköztürk, 2013: 98). Sabit terim değeri 5,134 olarak tespit edilmiştir. Bulunan sabit değer Presenteizm sıfır dahi olsa normatif bağlılık için 5,134 birimlik değer elde edileceğini açıklamaktadır. Presenteizm'deki bir birimlik artışın normatif bağlılığ1 -,338 birim azalttığı tabloda ifade edilen başka bir ifadedir (Kalayc1, 2010: 268).

Araştırma kapsamında belirlenen H1: “ỉşgörenin yaşadığ1 Presenteizm Durumunun Normatif Bağlllık üzerinde negatif ve anlamlı yönde bir etkisi vardır." hipotezine yönelik uygulanan 
regresyon analizi sonucu oluşturulan model anlamlı bulunmuş olup, $\mathbf{H}_{1 \mathrm{c}}$ hipotezi kabul edilmiştir.

Tablo 5. Regresyon Analizi

\begin{tabular}{|c|c|c|c|c|c|c|c|c|}
\hline \multirow[t]{2}{*}{ Model 1} & \multicolumn{2}{|c|}{$\begin{array}{c}\text { Standardize edilmemiş } \\
\text { katsayılar }\end{array}$} & \multirow{2}{*}{$\begin{array}{c}\begin{array}{c}\text { Standardize } \\
\text { edilmiş } \\
\text { katsayılar }\end{array} \\
\text { Beta }\end{array}$} & \multirow[t]{2}{*}{ t-değeri } & \multirow{2}{*}{$\begin{array}{l}\text { Anlam } \\
\text { düzeyi }\end{array}$} & \multicolumn{3}{|c|}{ Bağlantı İstatistikleri } \\
\hline & B & Std. Hata & & & & \begin{tabular}{|l|} 
Tolerans \\
\end{tabular} & VIF & CI \\
\hline (Sabit) & 5,134 & ,474 & - & 10,842 & , 000 & - & - & 1,000 \\
\hline Presenteizm &,- 338 & ,158 &,- 194 & $-2,144$ & ,034 & 1,000 & 1,000 & 12,603 \\
\hline \multicolumn{2}{|c|}{$\begin{array}{l}\text { Bağımlı değişken: } \\
\text { Normatif Bağlılık } \\
\text { DW: } 1,922\end{array}$} & & דיח & zeltilm & $\because \because, 0 Z$ & $F: 4,59$ & 0.0001 & \\
\hline
\end{tabular}

\section{TARTIŞMA, SONUÇ ve ÖNERİLER}

Yiyecek-İçecek işletmelerinde çalışanlarının maruz kaldığı presenteizm durumunun örgütsel bağlllık düzeyleri üzerinde herhangi bir etkisinin olup olmadığına yönelik gerçekleştirilen bu çalışmanın evrenini Adana ilinde faaliyet gösteren bütün yiyecek-içecek çalışanları oluşturmasına karşıllı örneklemini Adana ili içerisinde yer alan yiyecek-içecek işletmelerinde çalışan 150 kişi oluşturmaktadır. Araştırmaya en çok katılım erkekler tarafından sağlanırken, medeni durum bakımından en fazla katılımı bekarlar oluşturmaktadır. Yaş grubu bakımından en fazla cevaplanan yanıtın 18-24 olması, restoran işletmelerinde istihdam edilen kişilerin genç ve dinamik bir yapıya sahip olduğunu ifade etmektedir. Eğitim durumu bakımından en fazla katılımın "Lise" mezunu çalışanların oluşması ve katılımcıların sadece \%17'lik kısmının 'Lisans ve Lisansüstü eğitim durumu' mezunu olmaları, yiyecek-içecek işletmelerinde nitelikli-kalifiyeli personel ihtiyacı gereksinimini doğurmaktadır. En fazla katılım servis personelleri tarafından sağlanmıştır. İşletmede çalışma süresi bakımından en fazla yanıtlanan şık ‘ 5 yıl ve altı' dır. Bu durum işe giriş çıkış yoğunluğunun yüksekliğini göstermektedir. İşe yeni başlayan personelin adaptasyon süreci yaşayacak olmasından dolayı işe giriş çıkış oranının yüksek olmasının işletme açısından birtakım olumsuzlukları beraberinde getirebilecektir. Mevcut pozisyonda çalışma süresi sorusuna da katılımın en fazla ' 5 yıl ve altı' seçeneği üzerinden gerçekleştirilmesi ise restoran işletmelerinde istihdam edilen kişilerin çok da fazla deneyime sahip olmadıklarını ortaya koymaktadır.

Anket sorularına verilen yanıtların ortalamalarından hareketle katılımcıların Örgütsel Bağlılık düzeylerinin yüksek, alt boyutlarından olan normatif bağl1lık ve devam bağlılığı düzeylerinin yüksek olduğu belirlenmiş olup duygusal bağlılık düzeylerinin diğer alt boyutlara nazaran çok daha yüksek olduğu tespit edilmiştir. Katılımcıların büyük çoğunluğunun işletme içerisindeki faaliyetleri/görevlerini yürütmede isteklilik gösterdiği katılım düzeyinin duygusal bağlılığa daha çok artmasıyla birlikte anlaşılmaktadır.

Araştırma kapsamında belirlenen değiş̧kenler arasındaki ilişkiyi ölçmeye yönelik gerçekleştirilen korelasyon analizi sonrası presenteizmin sadece örgütsel bağlılı̆̆ın alt boyutlarından olan normatif bağlllık üzerinde, düşük düzeyde ve negatif yönde anlamlı bir ilişkisi tespit edilmiştir $(\mathrm{r}=,-194 \mathrm{p}<0,05)$. Bu ilişkiden hareketle bağımlı değişkenin bağımsız değişken üzerinde etkisini ölçmeye yönelik gerçekleştirilen basit doğrusal regresyon eşitliği testiyle presenteizmin duygusal bağlllık üzerinde negatif ve anlamlı yönde bir etkisinin olduğu anlaşılmıştır. Yani duygusal 
bağlılık düzeyleri yüksek olan katılımcıların presenteizm durumunu yaşamadığı ya da diğer bağlılık türlerine sahip olan katılımcılara göre daha az düzeyde yaşadığı anlaşılmaktadır.

Yöneticiler/amirler astlarını ve çalışanlarını her konuda takip etmeli, herhangi bir olumsuzluk sezmeleri sonrası çalışanlarıyla görüşmeli ve çözümlenebilecek bir husus varsa bu konuda yardımcı olarak personeli içerisinde bulunduğu presenteizm durumunu ortadan kaldırmalıdır. Yöneticiler astlarının ve işgörenlerin mesai saatlerini takip etmeli, iş yoğunluğu ne olursa olsun personelin rızası olmaksızın mesai baskısı yapılmamalılardır. Yöneticilerin rahatsızlı̆̆ını anlayamadığı, göz ardı ettiği durumlar işgörenin örgüte olan bağlılığı zamanla zayıflayabilir ve veriminin düşmesine neden olabilir. Böylesi bir durumun yaşanmaması adına yöneticilerin astları ve çalışanları ile sürekli olarak etkileşim halinde olmalı, onların da yönetimsel faaliyetlere katılımını sağlamalı ve her türlü faaliyette mutlaka fikirlerini almalıdır.

Personel rızası olmaksızın izin günlerinde iş yoğunluğundan kaynaklı off iptaline (izin günü iptali) gidilmemelidir. Personel üzerinde hastalık ya da herhangi bir fiziksel ya da ruhsal rahatsızlık hissedildiği an derhal personele istirahat raporu verilmeli ve sürecin takipçisi olunmalıdır. Presenteizm ve Örgütsel Bağlılık konusu güncel olmasından dolayı sınırlı sayıdaki araştırmacılar tarafından incelenmiştir. Özmen (2011) çalışmasında presenteizmin duygusal bağlılık ve normatif bağlılık arasında pozitif ve orta düzeyde bir ilişki tespit ederken Kendir, Arslan ve Özçelik Bozkurt (2018) çalışmalarında Presenteizmin "dikkat dağınıklılığı" boyutunun örgütsel bağllı̆̆ı̆ "devam boyutu" üzerinde pozitif yönde bir etkisinin olduğunu saptamıştır. Daha önceki çalışmalarda presenteizm ve örgütsel bağlılık değişkenleri arasında pozitif yönde bir ilişki ele alınmasına karşılık bu çalışmada negatif yönde bir ilişkinin olabileceği öne sürülmüştür. Araştırma sonucu elde edilen değerler presenteizm ve örgütsel bağlllık arasındaki etkiyi inceleyen herhangi bir çalışmanın sonuçlarıyla örtüşmemektedir. Araştırmanın daha önce herhangi bir hizmet sektörü ve yiyecek-içecek sektörü üzerinde gerçekleştirilmemesinden dolayı öncü bir çalışma niteliği taşımaktadır. Emek-yoğun ilişkisinin diğer sektörlere nazaran daha yaygın olduğu yiyecek-içecek işletmelerinde yaşanacak olan presenteizm durumu, üretim sürecini ve hizmet kalitesini doğrudan etkileyebilecek potansiyelde bir olumsuzluktur. Hizmet kalitesini belirleyen en önemli unsurun o hizmeti üreten ve sergileyen personel olduğu düşünülürse presenteizm özellikle hizmet sektöründe çok büyük bir olumsuzluk olarak ortaya çıkabilmektedir. Bu sebepten ötürü presenteizm ve örgütsel bağlllık hizmet sektörü içerisinde yer alan seyahat acenteleri, oteller, restoranlar ve diğer hizmet sektörü işletmelerinde çalışabilecek oldukça yüksek potansiyelde bir konudur.

$\mathrm{Bu}$ çalışmada araştırmanın gerçekleştirildiği örneklem içerisinde anket çalışmasına katılım sağlayan kişilerin anket sorularına herhangi bir baskı ve yönlendirme olmaksızın objektif bir şekilde cevapladıkları varsayılmıştır. Araştırma COVID-19 pandemi döneminde belirli sayıda faaliyet gösteren yiyecek-içecek işletmeleri ve bu işletmelerde istihdam edilen belirli sayıdaki işgören üzerinden gerçekleştirildiğinden dolayı araştırma sonuçlarının genellenmemesi gerekmektedir. Bu çalışma sadece bir il'de ve sınırlı sayıdaki yiyecek-içecek işletme çalışanları üzerine gerçekleştirilmiştir. Farklı bir evrende, zamanda ve farklı sektörler üzerine gerçekleştirilmesiyle daha farklı bulgulara ve sonuçlara ulaşılabilir, presenteizm'in demografik özelliklere göre durumu ve presenteizm durumunun farklı değişkenler ile arasındaki ilişki ve üzerindeki etki ortaya konarak bu olumsuzluğun ne şekilde absorbe/etkisiz hale getirilebileceği farklı önerilerle ortaya konulabilir. 


\section{KAYNAKÇA}

Allen, N. J. and Meyer, J. P. (1990). The measurement and antecedents of affective, continuance and normative commitment to the organization. Journal of Occupational and Organizational Psychology, 63(1), 1-18.

Ağırbaş, S. ve Yıldızhan, Ç. (2019). Presenteizm ile Örgütsel Bağlılık Arasındaki İlişki: Spor Genel Müdürlüğü Çalışanları Üzerine Bir Araştırma, Business and Management Studies: An International Journal, 7(4): 1291-1310.

Arronsson, G. and Gustafsson, K. (2005). Sickness Presenteeism: Prevalence, AttendancePressure Factors, and an Outline of a Model for Research, JOEM, 9(47): 958-966.

Balay, Refik. (2000). Yönetici ve Öğretmenlerde Örgütsel Bağlılık, Nobel Yayın Dağıtım, Ankara.

Baysal, İ. A., Baysal, G., Aksu, G. ve Aksu, N. (2014). Presenteeism (işte varolmama sorunu) ile örgütsel bağlllık arasındaki ilişki: Adnan Menderes Üniversitesi akademik personeli üzerinde bir uygulama. Electronic Journal of Vocational Colleges - Bürokon Özel Sayısı, 134-152.

Büyüköztürk, Ş. (2013). Sosyal Bilimler İçin Veri Analizi El Kitabı. Ankara: Pegem Akademi.

Coleman Daniel F., Gregory P. Irving, Christine L. Cooper (1999). Another Look at the Locus of Control- Organizational Commitment Relationship: It Depends on the Form of Commitment. Journal of Organizational Behavior, 20, 995-1001.

Coşkun, Ö. (2012). İki işyerinde işe devamsızlık ve kendini işe verememede etkili faktörlerin değerlendirilmesi. (Doktora Tezi). Ankara Üniversitesi, Sağlık Bilimleri Enstitüsü, Ankara.

Çetin, M. Ö. (2004). Örgüt Kültürü ve Örgütsel Bă̆glllk. Ankara: Nobel Yayın Dağıtım.

Çiftçi, B. (2010). İşte Var Olamama Sorunu ve İşletmelerin Uygulayabileceği Çözüm Önerileri. Çalışma ve Toplum Dergisi, 1(1), 153-174.

Çokluk, Ö., Şekercioğlu, G., ve Büyüköztürk, Ş. (2012). Sosyal Bilimler İçin Çok Değişkenli İstatistik SPSS ve LISREL Uygulamaları. Ankara: Pegem Akademi.

Erbaş, K. (2017). Presenteizm ile duygusal bağlılık arasındaki ilişki: seyahat acentaları üzerine bir uygulama. Yayınlanmamış Yüksek Lisans Tezi, Gazi Üniversitesi, Sosyal Bilimler Enstitüsü, Ankara.

Gül, H. (2002). Örgütsel Bağlllık Yaklaşımlarının Mukayesesi ve Değerlendirmesi. Ege Akademik Bakış Dergisi, 2(1), 37-56.

Janssens, H., Clays, E., Clerqo, B.D., Bacquer, D.D., Casini, F.K. and Braeckman, L. (2016). Association between Psychosocial Characteristics of Work and Presenteeism: A Cross-Sectional Study. International Journal of Occupational Medicine and Environmental Health, 29(2), 331-344.

Johns, G. (2010). Presenteizm in the workplace: a review and research agenda. Journal of Organizational Behavior, 31, 520-526.

Kalaycı, Ş. (2010). SPSS Uygulamalı Çok Değişkenli İstatistik Teknikleri. Ankara: Asil Yayın Dağıtım. 
Kaya, N. ve Selçuk, S. (2007). Bireysel başarı güdüsü organizasyonel bağlılığı nasıl etkiler?. Doğuş Üniversitesi Dergisi, 8(2), 175-190.

Kaygın E., Kerse G. ve Yılmaz T. (2017). Kamu Çalışanlarında Örgütsel Bağlılık ve Presenteeism Arasındaki İlişki: Kars İli Örneği, Obsudman Akademik Dergisi, 3(6), 181-204.

KIM, J., Suh, E.E., Ju, S., Choo, H., Bae, H. and Choi, H. (2016). Sickness Experiences of Korean Registered Nurses at Work: A Qualitative Study on Presenteeism. Asian Nursing Research, 10, 3238.

Kendir E., Arslan E. ve Özçelik Bozkurt H. (2018) Devam Bağlllığı, Presenteeism ve İşten Ayrılma Niyeti Arasındaki İlişki: Beş Yıldızlı Otel İşletmelerinde Bir Araştırma, İşletme Araştırmaları Dergisi, 10(4), 1029-1046.

Koçoğlu, M. (2007). İşletmelerde Presenteeism Sorunu ve İnsan Kaynakları Yönetimi Çerçevesinde Mücadele Yöntemleri, Yüksek Lisans Tezi, Yıldız Teknik Üniversitesi, Sosyal Bilimler Enstitüsü: İstanbul.

Koopman, C., Pelletier, K.R., Murray, J.F., Sharda, C.E., Berger, M. L., Turpin, R.S., Hackleman, P., Gibson, P., Holmes, D.M., and Ba, T.B. (2002). Stanford presenteeism scale: health status and employee productivity. JOEM, 44(1), 14-20.

Meyer, J.P. and Allen, N.J. (1991). A three-components conceptualization of organizational commitment. Human Resource Management Review, 1(1), 61-89.

Meyer, J. P. and Allen, N. J. (1984). Testing the side-best theory of organizational commitment: Some methodological considerations. Journal of Applied Psychology, 69(3), 372-378.

Mooi, E. and Sarstedt, M. (2011). A Concise Guide to Market Research the Process, Data and Methods Using IBM SPSS Statistics. Berlin: Springer.

Monojit C. and Tilley, C. J. (2002) Sickness, Absenteeism, Presenteeism, and Sick Pay, Oxford Economic Papers, 54, 669-687.

Mowday, R. T. and Porter, L. W., and Steers, R. M. (1982). Employee-organization linkages: The psychology of commitment, absenteeism, and turnover. New York: Academic Press.

Mowday, R. T. (1998). Reflections on the study and relevance of organizational commitment. Human Resource Management Review, 8(4), 387-401.

Özdamar, K. (2011). Paket Programlar ile İstatistiksel Veri Analizi. Eskişehir: Kaan Kitabevi.

Özdemir, N. ve Yılmaz, E. (2019). Algılanan Hizmetkâr Liderliğin Presentizm (Edimsizlik) Üzerindeki Etkisi: Frigya Bölgesi. Anatolia: Turizm Araştırmaları Dergisi, 30(3), 198-209.

Özmen, G. (2011), Presenteeism ile örgütsel bağ ilişkisi: Tekstil çalışanları üzerine bir araştırma, Yayınlanmamış Yüksek Lisans Tezi, Eskişehir Osmangazi Üniversitesi, Sosyal Bilimler Enstitüsü İşletme Anabilim Dalı, Eskişehir. 
Porter, L.W., Steers, R.M., Mowday, R.T. and Boulian, P.V. (1974) Organizational Commitment, Job Satisfaction, and Turnover among Psychiatric Technicians. Journal of Applied Psychology, 59, 603-609.

Puig-Ribera, A., McKenna, J., Gilson, N. and Brown, W.J. (2008). Measuring presenteesim in Catalan employees: linguistic adaptation and validation. International Journal of Workplace Health Management. 1, 198-208.

Randall, D.M. (1990). The consequences of organizational commitment: methodological investigation. Journal of Organizational Behavior. 11, 361-378.

Rantanen, I. and Tuominen, R. (2011). Relative Magnitude of Presenteeism and Absenteeism and Work-Related Factors Affecting Them Among Health Care Professionals. Int Arch Occup Environ Health, 84, 225-230.

Sanderson, K., Tilse, E., Nicholson, J., Oldenburg, B. and Graves, N. (2007). Which presenteeism measures are more sensitive to depression and anxiety?. Journal of Affective Disorders, 101, 65-74.

Şahin, S. (2016). İş görenlerin örgütsel bağlllık düzeylerinin presenteeismdeki rolü: Otel işletmelerinde bir uygulama, Yayınlanmamış Yüksek Lisans Tezi. Atatürk Üniversitesi, Sosyal Bilimler Enstitüsü, Erzurum.

Seçkin A.İ. ve Çakmak Y.Y. (2019), Presenteizm ile Örgütsel Bağlılık Arasındaki İlişki: Spor Genel Müdürlüğü Çalışanları Üzerine Bir Araştırma, BMIJ, 7(4): 1291-1310.

Sosyal Güvenlik Kurumu. (2021). SGK İstatistik Yıllıkları. Erişim Adresi http://www.sgk.gov.tr/wps/portal/sgk/tr/kurumsal/istatistik/sgk_istatistik_yilliklari (Erişim tarihi: 19.07 .2021$)$

Tavşanc1l, E. (2002). Tutumların Ölçülmesi ve SPSS ile Veri Analizi. Ankara: Nobel Yayınevi.

Turpin, R. S., Ozminkowski, R. J., Sharda, C. E., Collins, J. J., Berger, M. L., Billotti, G. M., Baase, C. M., Olson, M. J. and Nicholson, S. (2004). Reliability and validity of the Stanford presenteeism scale. Journal of Occupational and Environmental Medicine, 46, 1123-1133.

Yazıcıoğlu, Y. ve Erdoğan, S. (2004). SPSS Uygulamalı Bilimsel Araştırma Yöntemleri. Ankara: Detay Yayıncilık.

Yıldız, H. ve Yıldız, B. (2013). İş Yaşamında Presenteeism (Sözde Var Olma) Olgusu: Sağlık ve Verimlilik Açısından Önemi. 7. Ulusal Sağlık ve Hastane İdaresi Kongresi, 27-29 Eylül, Konya, 819830.

Zeffane, R. (1994). Patterns of Organizational Commitment and Perceived Management Style: A Comparison of Public and Private Sector Employees, Human Relations, 47(8): 977-1010. 